\title{
入院患者の持参薬調査から推察される服薬遵守状況
}

\author{
面谷幸子 ${ }^{1}$, 池嶋俊貴 ${ }^{1}$, 柴野雅仁 ${ }^{1}$, 勝井保弘 ${ }^{1}$, 初田泰敏 ${ }^{1}$ \\ 向井淳治 ${ }^{1}$, 畑中裕子 ${ }^{2}$, 菊内章夫 ${ }^{2}$, 関 源一 $^{2}$, 名徳倫明 ${ }^{* 1}$ \\ 大阪大谷大学薬学部実践医療薬学講座 ${ }^{1}$, 国保中央病院薬剂部 ${ }^{2}$

\section{Medication Compliance Status Inferred from Surveillance of Medicines Brought to Hospital by Inpatients}

\author{
Sachiko Omotani ${ }^{1}$, Toshiki Ikejima ${ }^{1}$, Masahito Shibano, ${ }^{1}$, Yasuhiro Katsui ${ }^{1}$, Yasutoshi Hatsuda', \\ Junji Mukai ${ }^{1}$, Yuko Hatanaka', Akio Kikuuchi', Genichi Seki ${ }^{2}$ and Michiaki Myotoku ${ }^{* 1}$ \\ Laboratory of Practical Pharmacy and Pharmaceutical Care, Faculty of Pharmacy, Osaka Ohtani University ${ }^{1}$, \\ Department of Pharmacy, Kokuho Chuo Hospital ${ }^{2}$ \\ $\left[\begin{array}{l}\text { Received March 26, } 2020 \\ \text { Accepted July 14, } 2020\end{array}\right]$
}

Several hospitalized patients have a history of medication use; consequently, there are numerous reports on the importance of pharmacists managing their own medications. Conversely, there is a lack of information about the status of patients' medication adherence. Therefore, we collected data on medicines brought to hospital by inpatients and investigated their medication compliance status. The medication compliance status of patients visiting the Kokuho Chuo Hospital from April 2017 to March 2018 was investigated using the identification sheets of medicines brought by these patients and patients' medical records. The number of differentiations of medicines brought to the hospital by inpatients was 1,080, and the details of 889 medicines were used in this study. The average number of medicines brought per patient was $5.6 \pm 3.5$, with elderly patients bringing more medicines and exhibiting a low medication compliance. Compliance with antibiotics, chemotherapeutics, and oncology drugs was good, whereas that of vitamins, peripheral nervous system agents, and drugs for treating sensory organ issues was poor. The cost of medication per patient among nonadherent patients was approximately 3,836 $\pm 11,078$ yen, amounting to a total cost of 3,409,914 yen. The medication compliance status inferred from this study was worse among elderly patients as well as for medicines used to treat chronic diseases. Pharmacists can provide appropriate drug treatments and contribute toward reducing healthcare costs by increasing awareness regarding the family pharmacist system and improving cooperation between community pharmacies and hospitals to improve polypharmacy and medication adherence.

Key words — medicines brought to hospital by inpatients, medication compliance, polypharmacy, elderly, family pharmacist, cooperation between community pharmacies and hospitals

\section{緒言}

入院患者の多くは，通院歴があり常用薬を服薬 していることが多いことから，入院時に服用薬を 持ち込むことが多い. 持参薬鑑別を服薬指導に活 かす取り組みや薬剤師の役割, 持参薬管理システ ムの構築や有用性など様々な持参薬への取り組み の報告 ${ }^{1-6)}$ や持参薬全体の服薬遵守状況の報告 ${ }^{7)}$
があるものの，患者の持参薬から推察される自宅 での服薬状況を薬効別に解析した報告や医療経済 に及ぼす影響などの報告はない. 2018 年度の診 療報酬改定では「入院時支援加算」が新設され， 入院の予定が決まった患者に対し, 入院中の治療 や入院生活に係る計画に備え入院前に持参薬の確 認などの支援を行い，患者および関係者と共有す る旨が定められた（https://www.jshp.or.jp/cont/18/

\footnotetext{
*テ584-8540大阪府富田林市錦織北3-11-1
} 
0219-1-0.pdf，2020年 2 月 25 日). しかし，包括 医療支払い制度を採用している病院では，薬剤費 が包括点に含まれるため治療目的の疾患に用いる 持参薬の使用は原則禁止とされているものの, 疾 患治療目的以外の薬剂は使用可能であることから 持参薬の取扱いが繁雑化して㧍り，持参薬に関連 するヒヤリ・ハット（http://www.med-safe.jp/pdf/ report_2018_4_R001.pdf，2020年 2月25日）やプレ アボイドなどの報告（https://www.jshp.or.jp/banner/ oldpdf/p55-6.pdf，2020 年 2 月 25 日）も多くあり， 薬剤師の担うべき業務は多い.

一方，本邦の医療費は年々増加しており，その 背景には，新たな医薬品の開発だけでなく，人口 の高齢化に伴う要因があると考えられる．本邦の 高齢者人口は現在 3,461 万人であり，人口に占め る割合は $27.3 \%$ （https://www.stat.go.jp/data/topics/ topi971.html，2020 年 2 月 25 日）と, 年々増加して いる. 高齢者は, 若年者に比べ薬物有害作用の発生 が多く, ${ }^{8-10}$ その要因として薬物動態の加齢変化に基 づく薬物感受性の増大や複数の併存疾患を治療す るため服薬薬剤数の増加などが問題となっている. 服薬薬片数の増加に伴い，薬剂費も増加しており (https://www5.cao.go.jp/keizai3/2017/08seisakukadai 13-0.pdf，2020 年 2 月 25 日)，薬剤師は，高齢者に 対するポリファーマシー対策を行う必要がある。ま た，2016年 4 月より「かかりつけ薬剂師・薬局」 制度が施行されたが，院内調剤を行っている病院 も存在し, 患者が複数の医療施設に罹っている場 合に本制度を利用できない現状も見受けられる。

薬剤師が薬物治療を行ううえで, 患者の服用薬 や服薬状況を把握することは非常に重要である。 そ こで，入院患者の自宅での服薬状況を明らかにする ために，持参薬の患者の服薬状沉を調査し，その 知見から，薬剤師は，患者に対しどのような取り組 みをする必要があるのかを検討したので報告する.

\section{方 法}

\section{1. 調査方法}

調査期間は， 2017 年 4 月〜 2018 年 3 月とし，国 保中央病院薬剤部が入院患者に対し持参薬鑑別を 行ったデー夕を調査した。調査には，持参薬鑑別
シートおよび電子カルテを用いた，得られた患者 情報は，患者毎に新たな番号により符号化し，他 者が個人を特定できないように配慮した。本研究 は,「人を対象とする医学系研究に関する倫理指針」 に基づき, 大阪大谷大学薬学部生命倫理委員会に て承認（承認番号：BE-0037-17）を得て実施した。

\section{2. 調査項目}

調査項目は, 年齢, 性別, 持参日, 持参薬名, 持 参薬の処方日および処方日数, 持参薬の個数とした. 薬剤情報提供文書またはお薬手帳より持参薬の処 方日および処方日数を調查し, 持参日より処方日を 減じることで服薬経過日数を算出した.ささらに, 処 方日数より服薬経過日数を減じることで持参薬の服 薬残日数を算出し, 持参薬の個数と比較することで 服薬遵守状況の確認を行った. 服薬遵守状況が良 好である場合には, [処方日数-（持参日 - 処方日 $)=$ 持参薬の個数 $/ 1$ 日服薬個数] のように等号で表す ことができる. 本研究では, 予定投与終了日の時点 で過剩となっている薬剤が 1 日服薬個数未満である もの $[0 \leqq$ 持参薬の個数 $/ 1$ 日服薬個数 - 拠方日 数-（持参日 - 処方日 $)\}<1]$ を服薬遵守されてい るもの，予定投与終了日の時点で過剩となっている

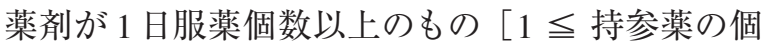
数 $/ 1$ 日服薬個数 $-\{$ 処方日数 - (持参日 - 処方日) $\}]$ を服薬遵守されていないものとし，その時の過剩と なった薬剤を残薬と定義した，さらに，対象患者を 年齢別の群として, 15 歳未満群 (小巟群), 15 歳以 上 65 歳未満群 (成人群), 65 歳以上 75 歳未満群 (前 期高齢者群）および 75 歳以上群（後期高齢者群） に分類した．薬効分類については，2018 年 11 月時 点の薬価基準収載医薬品コードを用い分類を行い, それを基に金額を算出し解析を行った。なお，これ らの情報のいずれかが不足しているものは調查対 象外とした．また，短期検査入院患者については， 持参薬鑑別を行っていないため調査対象外とした.

解析は, 持参薬の薬剂数および残薬金額の年齢 群別比較では Tukey 検定を用い, 薬価群による服 薬遵守率ではカイ二乗検定を用い, $P<0.05$ の場 合を有意差ありとした。なお，統計解析には IBM SPSS Statistics Desktop Ver.21（日本IBM(株), 東京) を用いた。 


\section{結果}

デー夕収集期間中での持参薬鑑別件数は 1,080 件で，調査対象となった持参薬の鑑別件数は 889 件，鑑別薬剂数は 4,963 件であった．また，対象 となった入院患者の平均年齢は $74.3 \pm 17.2$ 歳, 男性 $72.5 \pm 16.7$ 歳, 女性 $76.2 \pm 17.5$ 歳であった。 患者が持参した薬剤数は $5.6 \pm 3.5$ 剂であった

(表 1)。年齢別では，後期高齢者群が $6.1 \pm 3.3$ 凨と最も多く，小児群では $2.3 \pm 2.2$ 剂と年齢が 低いほど薬剤数は少ない傾向を示した。

服薬遵守率は平均 $26.0 \%$ で，年齢別では小览群 で $50.8 \%$ ，後期高齢者群では $23.7 \%$ と年齢が高く なるほど低值となった．残薬の平均日数（残薬個 数 $/ 1$ 日服薬日数) は, 全対象者で 8.5 日, 小児群
5.4 日, 成人群 7.9 日, 前期高齢者群 8.5 日, 後期 高齢者群 8.7 日であり, 年齢が高くなるほど, 残 薬日数が増加した. また, 残薬日数が 21 日以上の ものは，全体で $11.2 \%$ を占め，多いものでは 210 日分に及ぶものもあった（表 2, 図 1）。

表 1 年齢別持参薬鑑別件数および薬刘数

\begin{tabular}{|c|c|c|c|c|}
\hline 年齢別 & $\begin{array}{l}\text { 鑑別件数 } \\
\text { (件) }\end{array}$ & $\begin{array}{c}\text { 薬剂数 } \\
\text { (平均 } \pm \text { 標準偏差) }\end{array}$ & & \\
\hline 小児群 & 26 & $2.3 \pm 2.2 \neg$ & & \\
\hline 成人群 & 125 & $5.2 \pm 4.4$ & & \\
\hline 前期高齢者群 & 203 & $4.8 \pm 3.1=$ & NS & \\
\hline 後期高齢者群 & 535 & $6.1 \pm 3.3-$ & & \lrcorner \\
\hline 総計 & 889 & $5.6 \pm 3.5$ & & \\
\hline
\end{tabular}

小児群は 15 歳未満, 成人群は 15 歳以上 65 歳未満, 前期高齢 者群は 65 歳以上 75 歳未満，後期高齢者群は 75 歳以上を示す。 鑑別件数とは，持参薬を鑑別した患者数を示す. Tukey 検定.

NS: not significant, $\quad * P<0.01$.

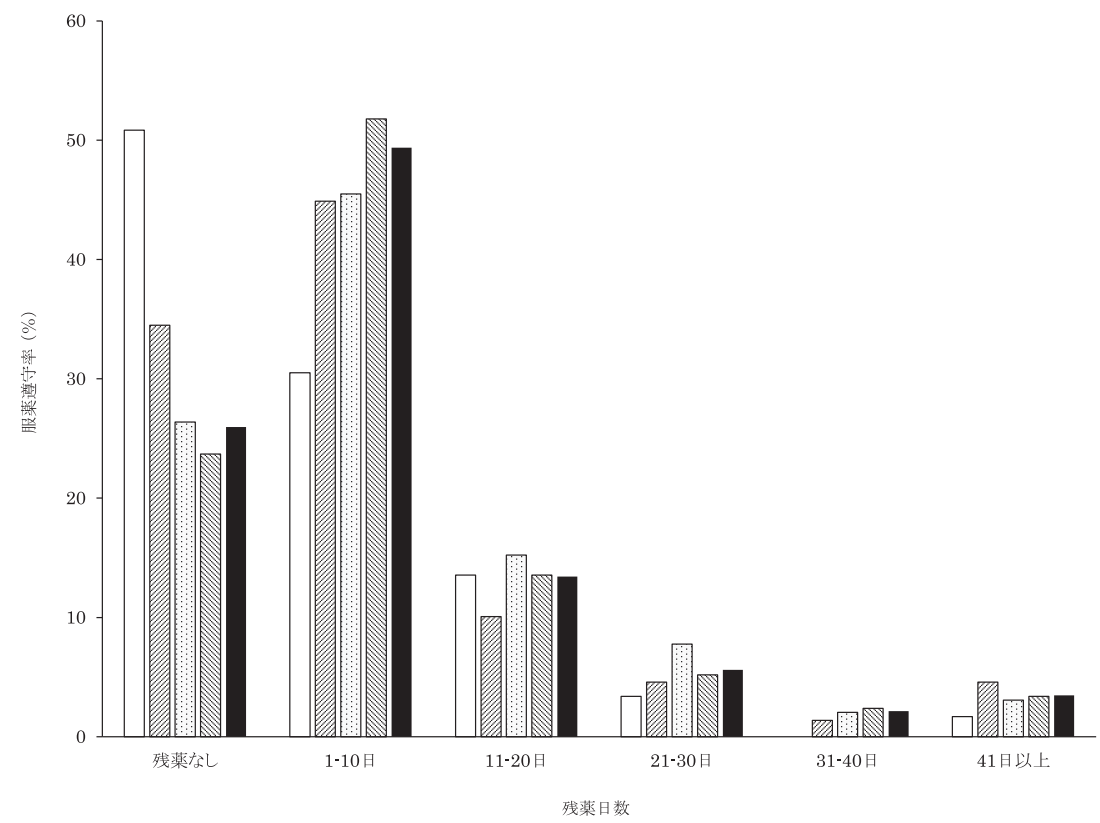

図 1 年歯別服薬遵守率および残薬日数 $\square$ 小览群，度成人群，目前期高齢者群，圈後期高齢者群，

総計

表 2 年齢別の服薬遵守率と残薬日数

\begin{tabular}{|c|c|c|c|c|}
\hline \multirow{2}{*}{ 年齢別 } & \multirow{2}{*}{$\begin{array}{c}\text { 薬剤数 } \\
\text { (件) }\end{array}$} & \multirow{2}{*}{$\begin{array}{c}\text { 服薬遵守率 } \\
(\%)\end{array}$} & \multicolumn{2}{|c|}{ 残薬日数（日） } \\
\hline & & & 平均 & 中央値 \\
\hline 小児群 & 59 & $50.8(30)$ & 5.4 & 1.0 \\
\hline 成人群 & 655 & $34.5(226)$ & 7.9 & 2.0 \\
\hline 前期高齢者群 & 978 & $26.4(258)$ & 8.5 & 4.0 \\
\hline 後期高齢者群 & 3,271 & 23.7（775) & 8.7 & 3.0 \\
\hline 総計 & 4,963 & $26.0 \quad(1,289)$ & 8.5 & 4.0 \\
\hline
\end{tabular}

小览群は 15 歳未満, 成人群は 15 歳以上 65 歳未満, 前期高齢者群は 65 歳以上 75 歳未満, 後期高齢者群は 75 歳以上を示す．服薬遵守率の（）内は服薬遵守件数を示す. 
表 3 薬効分類別からみた薬剤数, 服用遵守率および金額

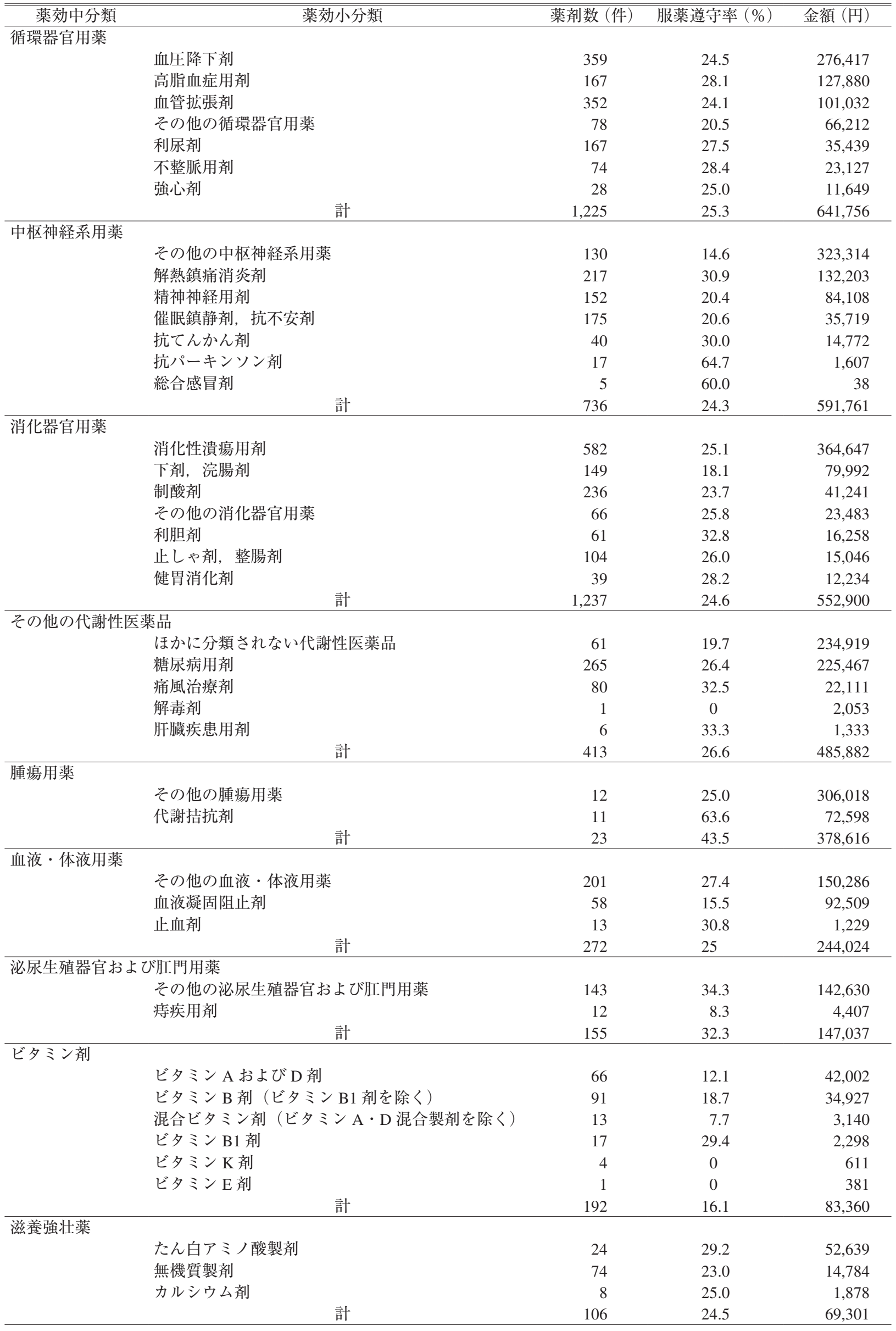


表 3 薬効分類別からみた薬剤数, 服用遵守率および金額（続き）

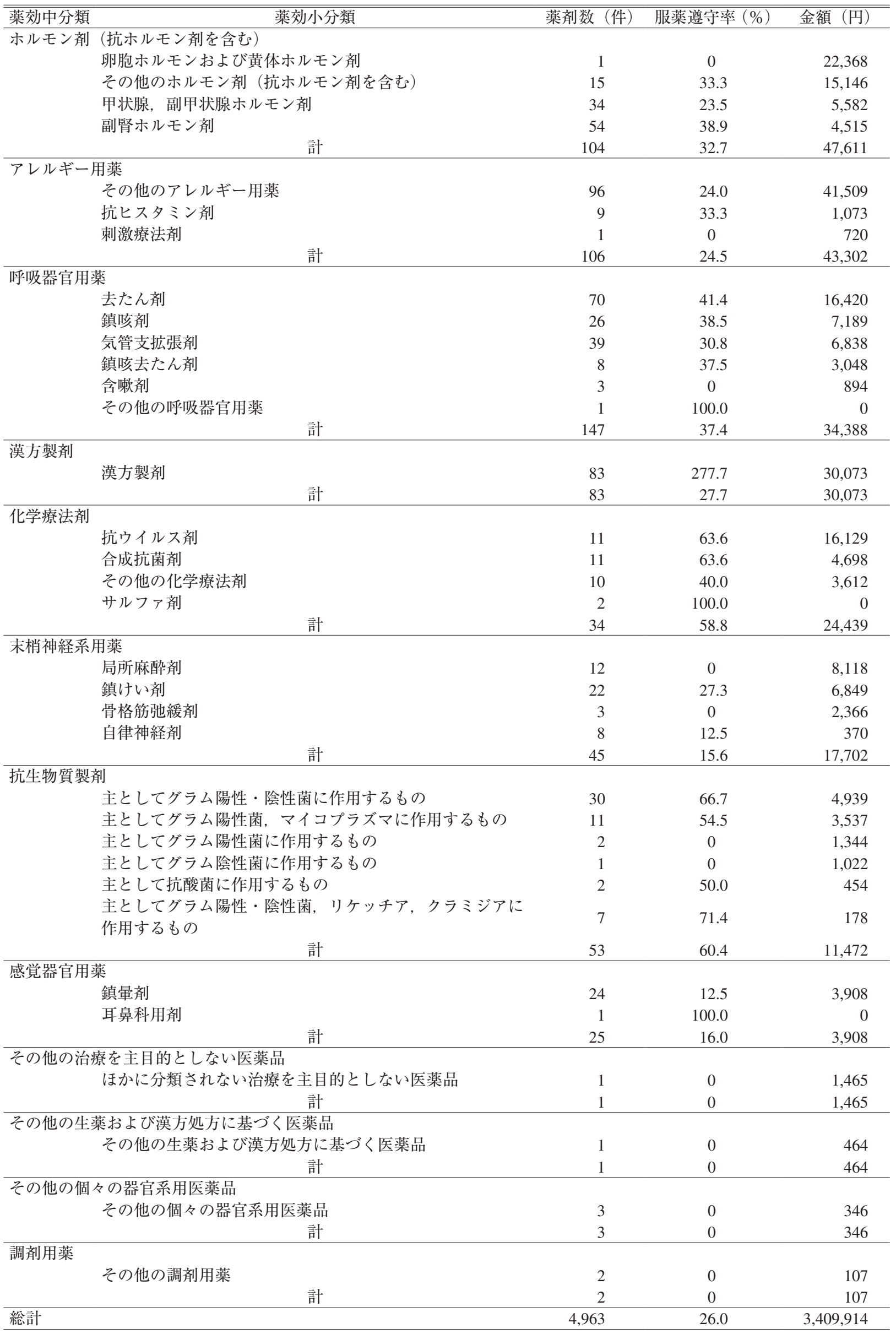




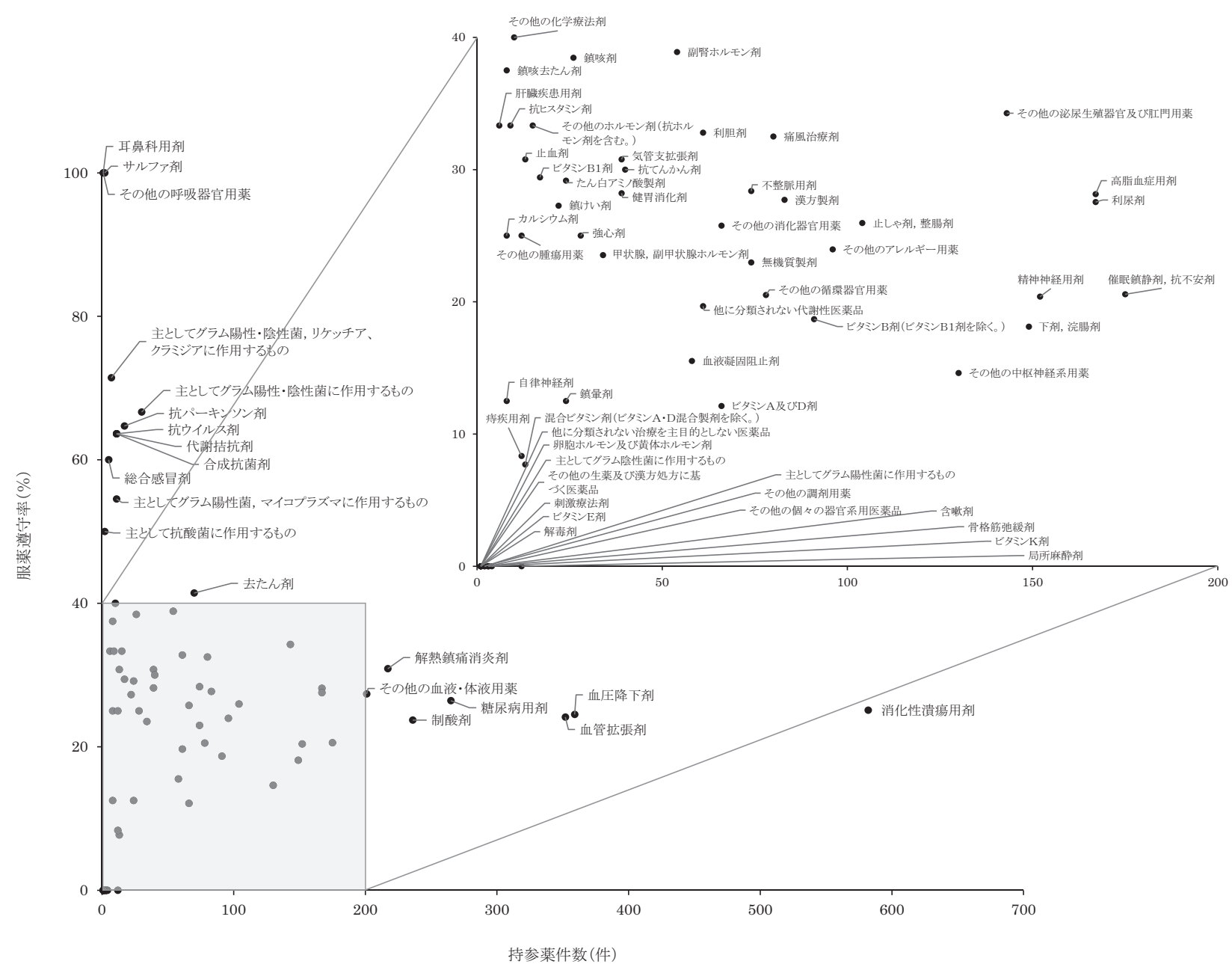

図 2 薬効分類（小分類）別の服薬遵守状況

薬効別の服薬遵守率では，抗生物質製剂や化学 療法剤, 腫瘍用薬が高く, ビタミン凨や末梢神経 系用薬，感覚器官用薬で服薬遵守率が低值であっ た．また，服薬遵守率が $40 \%$ 以下で持参薬剂数 が 200 件を超える薬剤が消化性潰瘍用剤，血圧降 下剤，血管拡張凨など多く存在した（図 2)。多 くの患者で服薬されていた消化器官用薬, 循環器 官用薬および中枢神経系用薬の服薬遵守率は約 $25 \%$ と低い傾向にあった。全残薬の薬価換算によ る金額は 3,409,914 円で，薬効別では循環器官用 薬 641,756 円と最も高く，次いで中枢神経系用 薬 591,761 円，消化器官用薬 552,900 円であっ た（表 3)．患者 1 人あたりの残薬金額の平均は $3,836 \pm 11,078$ 円で，年齢別では前期高齢者群で $5,148 \pm 17,859$ 円と最も高く, 小児群では $479 \pm$ 1,245 円と最も低かったが，有意な差は見られな かった（表 4)。一方，持参薬の薬剤単価の薬価
表 4 年齢別残薬金額

\begin{tabular}{lc}
\hline \hline \multicolumn{1}{c}{ 年齢別 } & 残薬金額 \\
小児群 & $479 \pm 1,245$ \\
成人群 & $3,866 \pm 13,655$ \\
前期高齢者群 & $5,148 \pm 17,859$ \\
後期高齢者群 & $3,494 \pm 6,224$ \\
\hline \multicolumn{1}{c}{ 総計 } & $3,836 \pm 11,078$ \\
\hline
\end{tabular}

単位：円. 小児群は 15 歳未満, 成人群は 15 歳以上 65 歳未満, 前期高齢者群は 65 歳以上 75 歳未満, 後期高齢者群は 75 歳以 上を示す. Tukey 検定の結果, 全ての群間において有意差はな かった.

群における服薬遵守率を検討したが，有意な差は 見られた $(P=0.031)$ が，金額による傾向は見ら れなかった（表 5). 
表 5 薬価別持参薬剤件数および服薬遵守率

\begin{tabular}{|c|c|c|c|}
\hline 薬価（円） & 薬荗数 (件) & 服薬遵守率（\%） & $P$ 值 \\
\hline $0-50$ & 3,593 & $25.4(912)$ & \multirow{6}{*}{0.031} \\
\hline $51-100$ & 643 & $26.1(168)$ & \\
\hline $101-500$ & 674 & 29.8（ 201） & \\
\hline $501-1,000$ & 21 & 23.8( & \\
\hline $1,001-5,000$ & 30 & 6.7( & \\
\hline $5,001-$ & 2 & 50.0( & \\
\hline 総計 & 4,963 & $26.0 \quad(1,289)$ & \\
\hline
\end{tabular}

\section{考察}

入院患者の多くは，通院歴があり何らかの薬剤 を服薬していることが多いことから，入院時に患 者の服薬状況を把握する必要がある。調查施設で は, 入院予定患者に対し, 事前に服薬状況を把握 し，手術予定患者においては，服薬を中止すべき 薬剤等の指導を行っている。薬剤師は，入院患者 に対し持参薬の確認を行い，持参薬鑑別用紙に薬 剤の処方発行元, 服薬の有無, 院内での代替薬な どを記載し主治医へ報告を行っている。 その際, 薬剤の持参薬の個数の確認は行っているが, 服薬 状況の詳細な把握はできていない。そこで，持参 薬鑑別時に得られた情報を集計し調査した。

服薬遵守率については, 次回受診日までの日数 に加え，予備の日数分を考慮し長期処方される場 合もあり，多少の残薬が発生する可能性があるこ とから, 実際の服薬遵守状況とは相違点もあるが, 本研究ではそのような余薬については考慮せず調 査を行ったため, 本来の服薬遵守率より低く評価 されている可能性がある。一方で, 本研究では, 服薬遵守率には，1 日服薬回数を評価に反映でき ていないことから，本来の服薬遵守率より高く評 価されていると考えられる．持参薬より服薬遵守 率を評価するには，実際の服薬遵守率と多少の差 異があり限界がある。しかし，持参薬を解析し， 推察される服薬遵守状況を明らかにすることは, 患者の薬物治療の向上にも有意義である. そこで, 本研究では，持参薬鑑別時に得られた情報を解析 し, 薬剤師が薬剤業務を行ううえでどのような取 り組みが必要であるか検討した。

調查期間の持参薬鑑別件数は, 後期高齢者群で 535 件と最も多く, 入院患者の多くが高齢者であ
り，1 患者あたりの持参された薬剤数は $6.1 \pm 3.3$ 剤とほかの年齢に比べ多い傾向にあったことか ら, 本研究より年齢が高いほど服薬されている薬 剂数が多いことがわかった。 また, 服薬遵守状況 は, 服薬剂数の多い高齢者ほど悪く, 後期高齢者 群で服薬遵守できている割合は $23.7 \%$ と若年層と 比較し顕著に低く，年齢が高いほど服薬遵守でき ていないことが明らかとなった。高齢者における 多剂併用は薬物有害事象の原因となることが報告 されている. ${ }^{8-10)}$ また，高齢者では，年齢を重ねるに つれ認知症率が上昇するなどの要因が加わり，ア ドヒアランス向上は非常に難しい. しかし，ノンア ドヒアランスにより,ささなる病状の悪化や薬剤の 過剩投与による有害事象発現が懸念されるため, 薬片師は，適正に服薬ができるよう努めなければ ならない. 薬剂師は患者の服薬状況を調查し, 同 種同効薬の重複投与や過量投与，相互作用などを 確認し, 適正な薬物療法が行われるよう, ポリ ファーマシーを解消するために，薬剤の必要性に ついても見直し，医師に提言していく必要がある.

一方, 薬效別では, 化学療法剂や抗生物質製剂, 腫瘍用薬などの服薬遵守率が高く, ビタミン剤や 末梢神経系用薬などの服薬遵守率が悪かった。 ま た, 多くの患者が服薬していた消化器官用薬や循 環器官用薬, 中枢神経系用薬の服薬遵守率は $25 \%$ 前後と低值であったことから，急性期疾患で 用いられる薬剤の遵守率が高く, 長期に渡り継続 し服薬しなければならない慢性期疾患に用いられ る薬剤の遵守率が悪い傾向にあることが明らかと なった。慢性期疾患の服薬期間は長期間に亘るた め, 残薬が多くなることが懸念されるが, 今回の 調查では初回投与開始時期の調查は行っていな い. 生活習慣病などの慢性期疾患においても, 服 
薬遵守率の低下により疾患の悪化につながるた め, 薬剤師は, 薬剤の重要性を患者に指導し理解 してもらい，さらには残薬状況等より服薬状況を 確認することで, 服薬遵守率を向上させることが 可能である.

服薬遵守できていない薬剤の金額は, 総計で 3,409,914 円，患者 1 人あたり 3,836 円であり，年 齢別では，遵守率が悪い高齢者で残薬金額が高 かった，薬効別では, 循環器官用薬が 641,756 円 と最も高額であり, 服薬遵守率が低值であるため に残薬金額が高值となっていることは明らかであ る. 一方, 腫瘍用薬では, 持参薬棛数 23 件, 服 薬遵守率 $43.5 \%$ とほかの薬片と比較し良好では あったが，薬剤費が高価であるため，残薬金額が 378,616 円と高額であった. 腫瘍用薬の残薬の理 由としては，有害事象の発現による服薬の中断が 多くを占めると考えられるが，ノンアドヒアラン スによる残薬であれば，治療にも大きく影響がで るものと考えられる。また，特に腫瘍用薬などの ハイリスク薬では，不適切な投与により重篤な有 害事象発現が懸念されるため, 適切な投与量や投 与期間の投薬状況の確認だけでなく，早期に有害 事象の発見ができるよう薬剤師は薬学的知識を身 に付け，日頃より患者とのコミュニケーションを 四り有害事象を未然に回避できるよう貢献してい かねばならない, 今回の調査結果では, 薬価各群 の服薬遵守率状況に差は見られた $(P=0.031)$ が, 薬価「1,001-5,000」群や「5,001-」群では, 薬 剂件数が少なく，また薬剤の種類に偏りがみられ た. 薬価「 $1,001-5,000 」$ 群では, 月 1 回服薬の 骨粗鬆症治療薬が多く含まれるなど，服薬遵守状 況が著しく不良であるとは言えず，実際の服薬遵 守率より低く評価されていると考えられる。薬価 各群と服薬遵守率での相関関係は認められず，服 薬遵守率は，薬剤金額より疾患によるものと考え られることから, 服薬指導の際には, 患者の病態 を把握したうえで, 服薬の重要性を伝える必要性 がある.

本研究では, 服薬状況を確認できる薬郕のみを 集計し，残薬金額を算出したことから，高額であ るインスリン製剤や吸入製剤などは含まれていな い. 高額な薬郕を加味することで, 残薬金額はさ
らに高額になることが予想される。調査施設は, 病床数 220 床, 入院患者の 1 日平均患者数約 150 人 (https://www.kokuho-hp.or.jp/files/original/20181 010090346189be3eaefe.pdf, 2020 年 2 月 25 日）の 中小病院である。これを, 本邦より報告されている 2019 年 5 月の一般病床の 1 日平均患者数 668,404 人 (https://www.mhlw.go.jp/toukei/saikin/hw/byouin/ m19/dl/1905kekka.pdf，2020 年 2 月 25 日）に換算 し算出すると, 残薬金額の薬剂費は, 1 年間で約 152 億となることが予測される。しかし，これは 一般病床だけであることから, 精神病床や結核病 床, 療養病床などの在院患者総数の 1 日平均患者 数は $1,221,607$ 人, 外来患者数 $1,272,991$ 人を加味す ると, 残薬金額はさらに高額な費用となることが 推測される.

残薬調整やポリファーマシー対策は, 入院期間 だけで解消されることは難しく, 特に急性期病院 では，平均在院日数が短期間であるためポリ ファーマシーへの対策が困難である場合も多い. 入院患者に対し，ポリファーマシー対策を行った 際に加算される薬剤総合評価調整加算があるよう に, 調剤薬局の薬学管理料には, 薬剤服用歴管理 指導料の加算に重複投薬 - 相互作用等防止加算 や，ポリファーマシー対策としての服用薬剂調整 支援料がある. 2016年度から「かかりつけ薬剂師・ 薬局」制度が開始され, 薬局薬剤師は, 患者の服 薬情報の一元的 - 継続的な把握と薬学的管理 - 指 導を実施することが求められている。しかし，か かりつけ薬郕師制度の普及は不十分であり，かか りつけ薬片師を指名している患者においても更な る指導が必要である ${ }^{11)}$ との報告もあることから， かかりつけ薬郕師の必要性を患者に理解してもら い, 利用してもらえるよう薬剤師は活動していか ねばならない。 そこで, 病院と地域の薬局が連携 をはかることで, 入院前から入院後までの服薬歴 や服用薬について，一元的な管理をすることが重 要であると考える. 薬学的判断に基づく疑義照会 は，処方の適正化だけでなく経済効果があり, ${ }^{12}$ また, 薬局と病院と事前に協定を結ぶことで, 疑 義照会の簡素化を進める施設も増えつつあり, 医 療効率を高めるだけでなく, 経済効果もあるとの 報告 ${ }^{13)}$ があることから, 薬薬連携をより一層進め 
ていく必要がある。

病院薬剤師は, 入院時の持参薬鑑別を入院患者 の服薬指導に活かし, さらには入院中や退院時に 指導を行った内容を地域の薬局薬剤師と情報共有 し，退院後や外来受診時にも継続した服薬指導が 行えるよう連携をしていく必要がある。薬郕師の適 切な薬物療法へのかかわりは，患者の服薬遵守率 の向上だけなく，本邦の医療経済にも貢献できる.

\section{利益相反}

開示すべき利益相反はない.

\section{引用文献}

1）金田覀季子, 大林恭子, 阿部正樹, 飯塚恵子, 中村 智徳, 山本康次郎, 入院患者持参薬を含む内服指 示書作成システムの確立, 医療薬学, 2010, 36, 599-604.

2）辻 泰弘, 平木洋一, 溝口晶子, 曽根本恵美, 平田 俊子, 横山吉博, 平尾幸一, 神村英利, 加留部 善晴, 電子カルテとリンクした持参薬管理システ ムの構築と医師・看護師による評価, 医療薬学, 2009, 35, 525-533.

3）森岡淳子, 田中亮裕, 宍野友紀, 井門敬子, 未丸 克矢, 荒木博陽, 腎機能低下患者における入院時 持参薬の使用実態と適正使用への取り組み, 医 療薬学, 2009, 35, 509-515.

4）門村将太, 鈴木智子, 浅野 尚, 福田由布子, 吉田 麻里, 鈴木聖奈子, 竹内美奈, 志賀隆博, 井藤達也, 竹本 功, 持参薬等管理業務の確立と薬剤師の 役割, 医療薬学, 2008, 34, 671-676.

5）渡邊裕之, 中井由佳, 持参薬鑑別報告書作成支援 システムの構築と評価, 医療薬学, 2007, 33, 913919.
6）遠原大地, 井上 真, 槇原洋子, 柴田七奈, 野田 佳子, 片桐文彦, 伊東弘樹, 武山正治, リスク回避 を目的とした入院時持参薬チェックシステムの 構築, 医療薬学, 2007, 33, 762-767.

7) 松本 篤, 山内祐人, 堀川泰清, 韓 秀妃, 循環器 病棟における持参薬チェックの完全実施とクリ ティカルパスへの応用に向けた取り組み, 日本 病院薬剤師会雑誌, 2010, 46, 800-803.

8）鳥羽研二, 秋下雅弘, 水野有三, 江頭正人, 金 承範, 阿古潤哉, 寺本信嗣, 長瀬隆英, 長野 宏一朗, 須藤紀子, 吉栖正雄, 難波吉雄, 松瀬 健, 大内尉義, 薬剂起因性疾患, 日本老年医学会雑 誌, 1999, 36, 181-185.

9) Rothschild JM, Bates DW, Leape LL, Preventable medical injuries in older patients, Arch Intern Med, 2000, 160, 2717-2728.

10）秋下雅弘, 寺本信嗣, 荒井秀典, 荒井啓行, 水上 勝義, 森本茂人, 鳥羽研二, 大学病院老年科にお ける薬物有害作用の実態調査, 日本老年医学会雑 誌, 2004, 41, 303-306.

11）國府田真綾, 鈴木 学, 金地夏実, 福本実咲, 桑原 千明, 林 秀樹, 亀山千里, 生木庸寛, 小原道子, 棚瀬友啓, 杉山 正, かかりつけ薬剂師を指名し ている患者の行動分析および意識調査, 医療薬 学, 2018, 44, 395-402.

12）神村英利, 山野 徹, 安高勇気, 大津友紀, 長郷 あかね, 小松公秀, 木原太郎, 高木純一, 緒方憲太 郎, 瀬尾 隆, 保険薬局における薬学的判断に基 づく疑義照会の経済効果, 薬理と治療, 2017, 45, 723-727.

13）櫻井香織, 尾崎淳子, 矢野育子, 安達昂一郎, 木村 嘉彦, 松村勝之, 西脇布貴, 吉田優子, 池見泰明, 萱野勇一郎, 米澤 淳, 深津祥央, 松原和夫, 病院 と薬局の合意に基づく院外処方せんにおける疑 義照会簡素化プロトコルとその効果, 医療薬学, 2016, 42, 336-342. 